\title{
A HOLSTEIN-FRIESIAN DAIRY FARM SURVEY OF POSTPARTURIENT FACTORS INFLUENCING THE DAYS TO FIRST AI AND DAYS OPEN IN HUNGARY
}

\author{
Dávid BUJÁk ${ }^{1,2}$, Zoltán SZELÉNYI ${ }^{1,2}$, Ali CHOUKEIR ${ }^{2}$, Levente KovÁCs ${ }^{2,3}$, \\ Fruzsina Luca KÉZÉR ${ }^{2,3}$, Szabolcs BoldizSÁR ${ }^{4}$, László MOLNÁR ${ }^{2}$ and Ottó SzENCI ${ }^{1,2 *}$ \\ ${ }^{1}$ University of Veterinary Science, Department and Clinic for Production Animals, \\ H-2225 Üllö, Dóra major, Hungary; ${ }^{2}$ MTA-SZIE Large Animal Clinical Research \\ Group, Dóra major, Üllö, Hungary; ${ }^{3}$ Institute of Animal Husbandry, Faculty of \\ Agricultural and Environmental Science, Szent István University, Gödöllő, Hungary; \\ ${ }^{4}$ Prograg Agrárcentrum Kft., Ráckeresztúr-Lászlópuszta, Hungary
}

(Received 16 February 2018; accepted 25 July 2018)

\begin{abstract}
The authors monitored the postpartum period during the first seven weeks after calving at a Holstein-Friesian dairy farm in Hungary. Calvings occurred between 2013 and 2015 in three periods from June to November each year $(\mathrm{n}=$ 314). Data were collected from the farm record and ultrasonographic examinations were performed between 22 to 28 and 43 to 49 days in milk (DIM), respectively. The animals were followed until successful artificial insemination (AI), i.e. until becoming pregnant or until culling, but at most at 365 DIM. The prevalence of dystocia, twin calving, stillbirth rate and retained fetal membranes (RFM) was $23.2 \%, 3.8 \%, 3.5 \%$, and $34.4 \%$, respectively. Altogether $38.9 \%$ of the cows $(\mathrm{n}=$ 122) had bacterial complications of involution in the first 49 DIM. The prevalence of Grade 2 clinical (puerperal) metritis (CM) was $20.1 \%$ within 5 DIM, $10.5 \%$ between 6 to 10 DIM and $13.1 \%$ from 11 to 20 DIM, while $9.9 \%$ of the cows had clinical endometritis (CEM) between 21 and 28 DIM and $1.3 \%$ of the cows between 42 and 49 DIM, respectively. Pyometra was diagnosed in $1 \%$ of the cows between 21 and 28 DIM and $0.3 \%$ between 42 to 49 DIM, respectively. About $80 \%(80.6 \%)$ of the cows were inseminated at least once $(n=253)$. The success rate of the first AI was $26.9 \%(n=68)$. Dystocia, twin calving, RFM, CM, CEM and cyclicity had no significant effect on the days between calving and first AI, however, according to the Kaplan-Meier analysis stillbirth significantly increased the number of days from calving to first AI $(P=0.039)$. According to the KaplanMeier analysis dystocia, twin calving, stillbirth, RFM, and cyclicity had no effect on the days open. In cows with CM developed within 5 DIM or with CEM diagnosed between 21 and 28 DIM the number of days open significantly decreased $(\mathrm{P}=0.009$ and $\mathrm{P}=0.007$, respectively), which confirms the importance of early diagnosis and treatment of uterine diseases. Similar surveys should be conducted to discover the risk factors for reproductive diseases in order to decrease the reproductive losses in dairy farms.
\end{abstract}

*Corresponding author; E-mail: Szenci.Otto@univet.hu; Phone: 0036 (29) 521-301; Fax: 0036 (29) 521-385 
Key words: Dairy cow, puerperal diseases, cyclicity, days to first AI, days open

Periparturient management of dairy cows plays a key role in reproductive performance. Over the past few decades, milk production has rapidly increased and, parallel with this trend, the fertility of cows decreased (Esposito et al., 2014); therefore, maintaining the reproductive performance of dairy cattle needs concentrated management activities, especially during the first 100 days in milk (DIM). Periparturient clinical and/or subclinical diseases and disorders may influence fertility. Decreasing conception rate and increasing number of days open may increase the calving interval and also the culling rate. Maizon et al. (2004) performed a survey on Swedish Red and White dairy cattle including more than 35,000 inseminations, and they found that dystocia, retained fetal membranes (RFM), metritis, ovulatory dysfunction and other diseases reduced the conception rate and increased the days from calving to first service.

Abnormalities during calving such as dystocia and stillbirth as well as twin calving may have a negative effect on the number of days open. A survey showed that calving assistance was associated with increased number of days from calving to first artificial insemination (AI) (Bell and Roberts, 2007). Dystocia increases the number of days to the first AI by 2.4 and to conception by 8.1 on the average (Fourichon et al., 2000). Twin calving also has a negative effect on fertility. Some authors found a significant association between twinning and conception to first AI (Berry et al., 2007; Inchaisri et al., 2010). The prevalence rate of stillbirth in a large Dutch survey including more than 50,000 lactations was 7.8\% (Inchaisri et al., 2010). Bicalho et al. (2007) found a 6.6\% stillbirth rate when analysing a total of 13,608 calvings in the USA, and the hazard rate of death/cull was $41 \%$ higher and the rate of diagnosed pregnancies was $24 \%$ lower for cows with stillbirth. Others reported similar results, i.e. that stillbirth reduced the conception rate both in primiparous and multiparous cows (Mangurkar et al., 1984; Moss et al., 2002; Maizon et al., 2004).

Uterine disorders such as RFM, metritis, endometritis and ovarian dysfunction are the most frequent abnormalities of the reproductive tract during involution and may influence the date of the first AI and the days open. RFM, which usually occurs with a frequency of $4-18 \%$, increases the risk of other reproductive disorders (Markusfeld, 1987; Han and Kim, 2005) and is associated with an increased number of days to first AI (by 7.4 days) as well as with prolonged days open (by 18 days). The effects of uterine infections on the reproductive system can be caused by delayed regeneration of the endometrium or a disruption of normal ovarian function (Földi et al., 2006). Puerperal metritis negatively affects fertility by increasing the days open and reducing the conception rate (Fourichon et al., 2000; Földi et al., 2006; Dubuc et al., 2010). Many authors have found that puerperal metritis lowers the fertility rate (Jorritsma et al., 2000; 
McDougall et al., 2007; Elkjær et al., 2013). Piccardi et al. (2016) reported a significant negative effect of puerperal metritis on fertility only in infected but not treated cows, while Maizon et al. (2004) found that cows with puerperal metritis had a reduced conception rate, although the difference did not reach the level of statistical significance.

The objective of our study was to evaluate the effects of normal calving and dystocia on the occurrence of RFM and postparturient uterine diseases (clinical metritis and endometritis) as well as on the interval from calving to the first $\mathrm{AI}$ and the length of the days open in a large-scale Hungarian Holstein-Friesian dairy farm.

\section{Materials and methods}

\section{Animals and housing}

The experiment was carried out at a large-scale dairy farm in Hungary (N47 18'191" E1848'336") with around 900 lactating Holstein-Friesian cows. The examinations were performed between 2013 and 2015 in three periods from June to November each year $(\mathrm{n}=314)$. The average 305 -day milk production was $8,638 \mathrm{~kg}$ in $2013,8,305 \mathrm{~kg}$ in 2014 and $8,178 \mathrm{~kg}$ in 2015 . After calving, the cows were housed in postpartum pens, each including four animals. Cows were fed a postpartum TMR ad libitum with a 60:40 forage to concentrate ratio on a dry matter basis. After calving, the cows were milked twice daily in a four-stall herringbone milking parlour (DeLaval International AB, Tumba, Sweden) during the first five DIM. After 5 DIM, healthy cows were introduced to the fresh lactation group and milked twice daily at 05:00 and 15:00 h in a $2 \times 28$-stall parallel Bosmark milking parlour (Bosmark Kft., Biatorbágy, Hungary).

\section{Study design and examinations}

The animals $(\mathrm{n}=314)$ were monitored from calving until 43 to 49 DIM. According to Mee et al. (2011), normal calving (eutocia) was regarded as a combination of 'no assistance' and 'slight assistance' by one person (where assistance was brief, traction slight and the cow may otherwise have calved unassisted). The incidence of dystocia was diagnosed based on the duration of the second stage of calving (initiated by rupture of the allantoic sac), judged by the absence of progression and straining without progress and, in the case of assisted births, the force applied, as follows. Prolonged spontaneous calvings $(>1 \mathrm{~h}$ from the appearance of hooves to delivery) and calvings with assistance by two or more people with considerable force (with a calving rope or by using a calf puller during delivery) were regarded as dystocic. In this way dystocia was evaluated as a dichotomous (yes/no) variable. Stillbirth was defined as the death of a mature calf after 260 days of gestation during calving or within 24 to 48 hours after parturition (Szenci and Kiss, 1982; Mee, 1991). 
Every cow had at least six examinations during the involution period. Each cow was checked from 12 to $24 \mathrm{~h}$ after calving for RFM by transvaginal examination and on 5 DIM and between 6-10 and 11-20 DIM for Grade 2 clinical (puerperal) metritis $(\mathrm{CM})$ by transrectal palpation. $\mathrm{CM}$ was diagnosed when fetid red-brown watery uterine discharge, atonic enlarged uterus and pyrexia $\left(>39.5^{\circ} \mathrm{C}\right)$ were found (Sheldon et al., 2009). From 22 to 28 and from 43 to 49 DIM, transrectal ultrasonography with a $7.5-\mathrm{MHz}$ linear array transducer (Easi-Scan bovine scanner, BCF Technology Ltd., Bellshill, United Kingdom) was used to diagnose clinical endometritis/pyometra (CEM). CEM was diagnosed if echogenic fluid was found in the uterine cavity and/or purulent vaginal discharge in the vulva was presented after transrectal massage of the uterus. Pyometra was diagnosed when echogenic fluid was seen in the uterine cavity together with a corpus luteum, but purulent vaginal discharge was not present in the vulva because of the closed cervix (Sheldon et al., 2009). Ovarian structures such as corpus luteum and follicles were examined and recorded as well.

If RFM occurred, efforts were made to pull out the placenta by gentle traction and $2000 \mathrm{mg}$ of tetracycline hydrochloride (Tetra-Bol 2000 intrauterine tablet A.U.V., CP-Pharma Handelsges. GmbH, Germany) was administered into the uterus for the prevention of CM. This intrauterine treatment was repeated 2 or 3 times on every second day according to the label. If CM developed with or without RFM, $500 \mathrm{mg}$ ceftiofur (Excenel RTU inj. A.U.V., Pfizer Manufacturing Belgium N.V./S. A.) was given subcutaneously for 3 to 5 days. If CM developed between 6 and 21 DIM, ceftiofur treatment was performed or repeated (in the case of recurrence) as mentioned previously. The milk production was controlled in the farm and, if there was a decreased milk yield in the first three weeks, the cows were examined for the incidence of CM as well. If CEM occurred, $500 \mathrm{mg}$ of cefapirin (Metricure intrauterine suspension A.U.V., Intervet International B. V.) was given by intrauterine administration. In case of pyometra $0.526 \mathrm{mg}$ cloprostenol sodium (PGF Veyx forte inj. A.U.V., Veyx Pharma B. V.) was given and 3 days later, when luteolysis occurred, the treatment was the same as for CEM (Szenci, 2016).

Data associated with involution such as dystocia, twin calving, stillbirth, RFM and CM presenting in the first 3 weeks after calving were collected from the farm management software (RISKA, Systo Ltd., Budapest, Hungary). After the involution period the cows were followed up until the first successful AI or culling but at most for one year after calving. The date and the result of each AI were recorded. The inseminated cows were checked for pregnancy by means of transrectal ultrasonography using an Easi-Scan bovine scanner between 28 to 35 days after service. 


\section{Statistical analysis}

The Kaplan-Meier estimator of survival is a nonparametric estimator of the survival function or the survival curve $\mathrm{S}(t)$, which is calculated by the formula

$$
\mathrm{S}(t)=\mathrm{P}(\mathrm{T} \geq t)=1-\mathrm{F}(t),
$$

where $\mathrm{T}$ is the survival time with a probability distribution $\mathrm{F}(t)$ and probability function $\mathrm{f}(t)$. If all the failure times at which the event occurs are ordered and labelled $t_{\mathrm{j}}$ such that $t_{1} \leq t_{2} \leq \ldots \leq t_{\mathrm{n}}$, the Kaplan-Meier estimator is calculated by the formula

$$
\hat{S}(t)=\prod_{j \mid t_{j} \leq t}\left(1-\frac{d_{j}}{n_{j}}\right),
$$

where $d_{\mathrm{j}}$ is the number of animals who experienced the event at time $t_{\mathrm{j}}$ and $n_{\mathrm{j}}$ is the number of animals who have not yet experienced the event at that time and are therefore at risk of experiencing it, including those censored at $t_{\mathrm{j}}$. The product is over all failure times less than equal to $t$.

The logrank test is a rank test that can be viewed as an extension of the Mantel-Haenszel test applied to survival data. Assume that we are interested in comparing the survival experience of the $r$ groups. Assume also that, in all groups combined, there are $k$ distinct failure times, and that at failure time $t_{j}$ there are $n_{\mathrm{j}}$ animals at risk, of which $d_{\mathrm{j}}$ fail and $n_{\mathrm{j}}-d_{\mathrm{j}}$ survive. Then the log-rank test statistic is computed by combining the information from the contingency tables obtained at every failure time by constructing at each of the $k$ distinct failure times an $r \times 2$ contingency table and then combining results from these $k$ tables. With the logrank test we can take into account the entire survival experience and not just a specific point in time.

For each time $t_{\mathrm{j}}$ the expected number of failures in group $i$ at time $t_{\mathrm{j}}$ under the null hypothesis of no difference in survival among the $r$ groups is $E_{\mathrm{ij}}=n_{\mathrm{ij}} d_{\mathrm{j}} / n_{\mathrm{j}}$. The chi-squared test is then calculated, which has a $\chi^{2}$ distribution with $r-1$ degrees of freedom under the null hypothesis.

If the observed values are different enough from the expected value to produce a highly significant chi-squared value, then with the log-rank test we can reject the null hypothesis that the survivor functions of the two groups are the same (Cleves et al., 2010).

\section{Results}

Altogether 314 calvings were monitored (Table 1). The prevalence of dystocia, twin calving, stillbirth rate and RFM were $23.2 \%(\mathrm{n}=73), 3.8 \%(\mathrm{n}=12)$, $3.5 \%(\mathrm{n}=11)$, and $34.4 \%(\mathrm{n}=108)$, respectively. Dystocia significantly increased the prevalence of RFM $(\mathrm{P}<0.000)$ and CM $(\mathrm{P}<0.000)$, while CEM $(\mathrm{P}=0.451)$ was not influenced (data not shown). The prevalence of $\mathrm{CM}$ was 
$20.1 \%(\mathrm{n}=63)$ in the first five DIM, $10.5 \%(\mathrm{n}=33)$ from 6 to 10 DIM and $13.1 \%(\mathrm{n}=41)$ from 11 to 20 DIM. The prevalence of CEM was $9.9 \%(\mathrm{n}=31)$ from 22 to 28 DIM and $1.3 \%(n=4)$ from 43 to 49 DIM. Three cows $(1 \%)$ had pyometra diagnosed between 22 and 28 DIM and another 1 cow $(0.3 \%)$ between 43 and 49 DIM. Altogether $38.9 \%(n=122)$ of the cows had bacterial complications during the involution period: 100 cows had clinical metritis, while 22 cows had clinical endometritis.

Table 1

Prevalence rate of reproductive conditions and their correlation to days to first AI and days open $(\mathrm{n}=314)^{*}$

\begin{tabular}{lrrcc}
\hline & $\begin{array}{c}\text { Ratio } \\
\%\end{array}$ & $\mathrm{n}$ & $\begin{array}{c}\text { Days to first AI } \\
\text { P value }\end{array}$ & $\begin{array}{c}\text { Days open } \\
\text { P value }\end{array}$ \\
\hline Dystocia & 23.2 & 73 & 0.213 & 0.211 \\
Twinning & 3.8 & 12 & 0.525 & 0.585 \\
Stillbirth & 3.5 & 11 & $\mathbf{0 . 0 3 9}$ & 0.979 \\
RFM & 34.5 & 108 & 0.208 & 0.157 \\
CM day 5 DIM & 20.1 & 63 & 0.675 & $\mathbf{0 . 0 0 9}$ \\
CM 6 to 10 DIM & 10.5 & $33^{1}$ & 0.406 & 0.939 \\
CM 1 to 20 DIM & 13.1 & $41^{2}$ & 0.133 & 0.798 \\
CEM 22 to 28 DIM & 9.9 & 31 & 0.231 & $\mathbf{0 . 0 0 7}$ \\
CEM 43 to 49 DIM & 1.3 & 4 & 0.493 & 0.161 \\
CL 22 to 28 DIM & 50.5 & 158 & 0.201 & 0.061 \\
CL 43 to 49 DIM & 56.9 & 178 & 0.337 & 0.137 \\
\hline
\end{tabular}

RFM - retained fetal membranes, CM - clinical metritis, CEM - clinical endometritis, CL - presence of corpus luteum, DIM - days in milk; ${ }^{*}$ one cow was culled immediately after calving; ${ }^{1}$ out of $33 \mathrm{CM}$ cases from 6 to 10 DIM 25 were recurrent clinical metritis; ${ }^{2}$ out of $41 \mathrm{CM}$ cases from 11 to 20 DIM 12 were recurrent clinical metritis and in 7 cases the first clinical metritis developed during the first 5 days after calving

The first ultrasonographic examination performed between 22 and 28 DIM demonstrated that $50.3 \%(\mathrm{n}=158)$ of the cows had a corpus luteum as a proof of cyclic ovarian activity, since these cows had at least one ovulation. Of the corpora lutea, $29.1 \%(\mathrm{n}=46)$ had a cavity. The second ultrasonographic examination performed between 43 and 49 DIM showed that $56.7 \%(n=178)$ of the cows had a corpus luteum. The ratio of corpora lutea with cavity was $32.0 \%(\mathrm{n}=57)$.

The effects of dystocia, twin calving, stillbirth, RFM, CM and CEM on the interval from calving to first AI are shown in Table 1. Only cows having at least one AI were included in the statistical analysis. The effect of ovarian cyclic activity on the days to first AI was also evaluated at two different intervals. The analysis demonstrated that dystocia, twin calving, RFM, CM and the presence of ovarian cyclic activity between 22 and 28 DIM, and also between 43 and 49 DIM, had no significant effect on the interval between calving and the first AI. At the 
same time, cows with stillbirth had a longer time interval between calving and first AI than cows with normal calving $(\mathrm{P}=0.039)$ (Fig. 1).

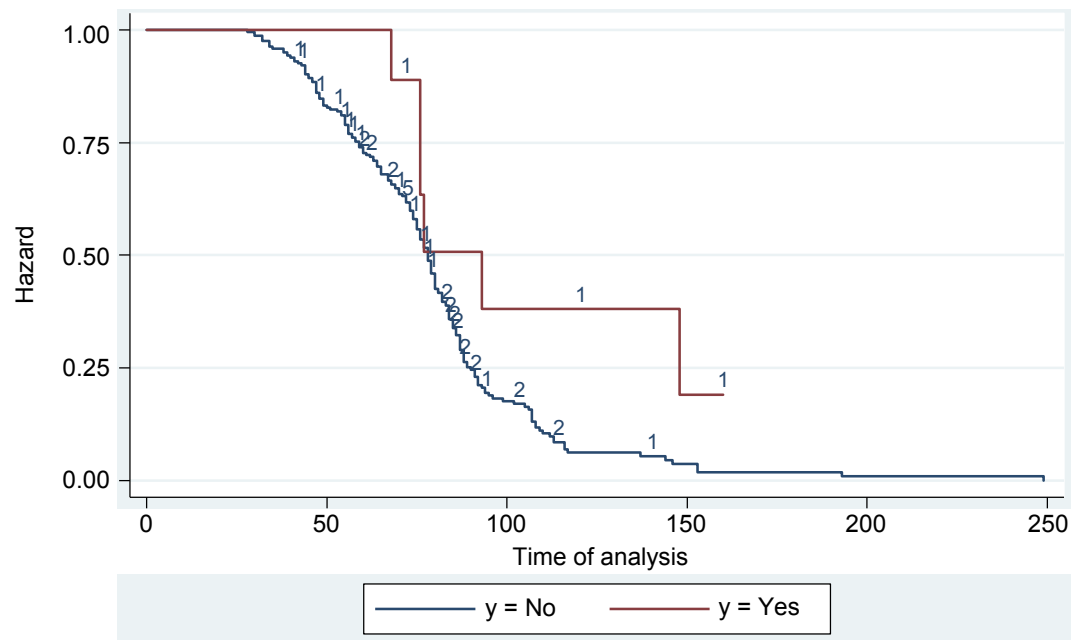

Fig. 1. The effect of stillbirth on the number of days to first AI. Time between parturition and first artificial insemination (days) (hazard by stillbirth [y])

The effects of dystocia, twin calving, stillbirth, RFM, CM and CEM on the number of days open for cows that became pregnant within 365 DIM are presented in Table 1. There were no significant differences between dystocia, twin calving, stillbirth, RFM and the presence of ovarian cyclic activity between 22 and 28 and also between 43 and 49 DIM and the days open. Cows suffering from $\mathrm{CM}$ within 5 DIM had shorter days open than those which did not have CM during that period $(\mathrm{P}=0.009)$. Cows having $\mathrm{CEM}$ diagnosed between 22 and 28 DIM also had significantly shorter days open than those without CEM ( $\mathrm{P}=$ 0.007). CM occurring between 6 and 20 DIM and CEM developing between 43 and 49 DIM had no significant effect on the length of days open $(\mathrm{P}=0.939$ between 6 and 10 DIM, $P=0.798$ between 11 and 20 DIM and $\mathrm{P}=0.161$ between 43 and 49 DIM) (Table 1).

Altogether $26.4 \%(n=83)$ of the cows were culled before getting pregnant, $3.2 \%(\mathrm{n}=10)$ of the cows were culled in the first three weeks after calving, while $21.0 \%(n=66)$ of the cows were culled before the first AI after calving. RFM and CM had no effect on the interval until first AI and on the days open (Table 2); however, when intramuscular antibiotic treatments due to clinical metritis were performed, somewhat less days were needed for the first AI and days open, but the differences among the groups did not reach a statistically significant level. At the same time, the culling rate was significantly higher $(\mathrm{P}=$ 0.0326) when CM developed without RFM, compared with cows with RFM 
without CM. The culling rate was more than three times higher (OR: 3.103, 95\% CI: $1.178-8.175)$ in cows developing CM than in cows with RFM, the difference being statistically significant $(\mathrm{P}=0.0219)$.

Table 2

Effect of retained fetal membranes (RFM) and clinical metritis (CM) on culling, days to first AI and days open $(\mathrm{n}=313)$

\begin{tabular}{lcccc}
\hline & Culling & \multicolumn{2}{c}{ Days to first AI } & Days open \\
\cline { 3 - 4 } Types of uterine diseases & $\mathrm{n}(\%)$ & $\mathrm{n}(\%)$ & Mean \pm SD & Mean \pm SD \\
\hline RFM without CM & $8^{\mathrm{a}}(2.6)$ & $45(14.4)$ & $84 \pm 60$ & $155 \pm 95$ \\
RFM with CM & $15(4.8)$ & $40(12.8)$ & $78 \pm 48$ & $116 \pm 73$ \\
CM without RFM & $16^{\mathrm{b}(5.1)}$ & $29(9.3)$ & $72 \pm 22$ & $118 \pm 61$ \\
No CM and no RFM & $44(14.1)$ & $116(37.1)$ & $86 \pm 46$ & $149 \pm 79$ \\
\hline
\end{tabular}

${ }^{\mathrm{a}, \mathrm{b}}$ Values marked with different superscripts are significantly different at $\mathrm{P}=0.0326$

\section{Discussion}

The prevalence of dystocia may vary between 2 and $14 \%$ internationally (Mee, 2008); however, this finding applies to pasture-based small farms. In contrast, the prevalence rate of dystocia in the large-scale dairy farm investigated in this study was $23.3 \%$, which is consistent with findings reported previously by us (22.3\%; Szenci et al., 1987) and by other authors (23.4\%; Laster and Gregory, 1973); however, Meyer et al. (2000) reported somewhat lower prevalence rates for dystocia (overall: $9.3 \% ; 19 \%$ for heifer calving and $6 \%$ for cow calving). The prevalence of twinning (3.8\%) observed in this study was similar to that found in other studies (Silva del Rio et al., 2007), while stillbirth rate proved to be slightly lower than reported earlier (Bicalho et al., 2007; Inchaisri et al., 2010). The fact that the data were collected between June and November in each year of study may have influenced the stillbirth rates (Szenci et al., 1987). The frequency of RFM was $34.4 \%$, which was much higher than in other studies (Markusfeld, 1987; Han and Kim, 2005). Although the exact reason for this high prevalence rate of RFM was not examined in this study, we have recently demonstrated that in cases of premature obstetrical assistance (from 5 to 48 min after the appearance of fetal hooves vs. appropriately timed obstetrical assistance from 68 to $82 \mathrm{~min}$ after the appearance of fetal hooves) the prevalence of RFM increased significantly (Kovács et al., 2016). In agreement with the findings of a previous study (Bell and Roberts, 2007), dystocia (calving assistance by two or more people) also significantly increased the prevalence of RFM and CM in our study.

The prevalence of CM, CEM and pyometra varies within a wide range in different studies, and our results may are more or less consistent with the previ- 
ous findings (Bell and Roberts, 2007). In line with the results of Hadley et al. (2006) who found a $31.6 \%$ culling rate in the USA, the culling rate from calving to conception was $26.4 \%$ in the present study.

The interval from calving to the first $\mathrm{AI}$ and the days open depend on many factors. These parameters have an effect not only on fertility but on other factors as well. Cows with RFM, stillbirth, dystocia or twin calving are at an increased risk of developing CM during involution (Potter et al., 2010), while dystocia is associated with twinning and stillbirth (Bicalho et al., 2007). Thus, these factors can have direct or indirect effects on fertility. In the present study, only those factors were examined which might have a direct effect on days to first AI and days open. We did not find any significant relationship between days open and stillbirth, but cows giving birth to stillborn calves had an increased number of days open from calving to first AI. These findings are in agreement with those of previous studies, because many researchers have found associations between stillbirth and fertility (Maizon et al., 2004; Bicalho et al., 2007). The reason why we found correlation only with the number of days to first AI could be again the low number of cases (5/11) as mentioned previously. It is important to mention that some authors have found an association between twinning and reduced fertility (Berry et al., 2007; Inchaisri et al., 2010); however, due to the relative low number of our cases we were not able to confirm their findings. We included in the analysis only those twinning cows which became pregnant within one year after parturition (8/12) or had at least one insemination (9/12).

RFM is a risk factor for periparturient reproductive and metabolic disorders that decrease fertility (Gröhn et al., 1989). Although cows with RFM had increased number of days to the first AI and days open (Table 2), the differences were not statistically significant. Most authors found associations between RFM and days to first AI or days open (Han and Kim, 2005), while others could not demonstrate such correlations (Fourichon et al., 2000).

In the statistical analysis, we examined separately the effect of CM and CEM occurring at different time periods on fertility. This indicated that cows with $\mathrm{CM}$ occurring before 5 DIM had significantly decreased numbers of days open, while the number of days open in cases of CM occurring in other time periods did not differ. Several authors have also found a significant correlation between CM and days open (Jorritsma et al., 2000; Bell and Roberts, 2007; McDougall et al., 2007; Elkjær et al., 2013). On the other hand, Maizon et al. (2004) could not find any significant differences regarding days open between cows with $\mathrm{CM}$ and the control group. It is possible that CM occurring in different time periods during involution may influence the fertility in different ways. We did not find any study using the same subdivisions for CM in the literature. Therefore, further studies are needed to confirm the effect of CM diagnosed between different time periods after calving on fertility. In agreement with the findings of a recent study (Okawa 
et al., 2017), CEM occurring between 22 and 28 DIM and treated with intrauterine antibiotics also had a significant positive effect on the days open.

We did not find any correlation between the type of the ovarian structures and the days to first AI or the days open; however, several authors have found correlations between anoestrus and the days open (Harman et al., 1996; Ouweltjes et al., 1996; Fourichon et al., 2000). This might be because we only evaluated the ovarian structures. During ultrasonographic examinations the corpus luteum was evaluated as the proof of ovulation; however, the lack of a corpus luteum is not a proof of an anoestrus case. Further examinations are needed to obtain general results about conditions possibly influencing the days to first AI and the days open. Evaluation of the effects of CM occurring in different time periods on the conception rate is also necessary.

\section{Acknowledgements}

The authors thank Ferenc Bodó, the owner and Ágoston Bodó, the general manager of the farm for supporting the study, as well as the farm staff of Prograg Agrárcentrum Ltd. at Ráckeresztúr-Lászlópuszta for taking care of the animals during the period of study. Levente Kovács was supported by the following grants: [1] János Bolyai Research Scholarship of the Hungarian Academy of Sciences, [2] OTKA Postdoctoral Research Grant by the National Research, Development and Innovation Office (PD123456), [3] the New National Excellence Project (ÚNKP-17-4-1/SZIE), and [4] the Research Center of Excellence Project (1476-4/2016/FEKUT).

\section{References}

Bell, M. J. and Roberts, D. J. (2007): The impact of uterine infection on a dairy cow's performance. Theriogenology 68, 1074-1079.

Berry, D. P., Lee, J. M., Macdonald, K. A. and Roche, J. R. (2007): Body condition score and body weight effects on dystocia and stillbirths and consequent effects on postcalving performance. J. Dairy Sci. 90, 4201-4211.

Bicalho, R. C., Galvao, K. N., Cheong, S. H., Gilbert, R. O., Warnick, L. D. and Guard, C. L. (2007): Effect of stillbirth on dam survival and reproduction performance in Holstein dairy cows. J. Dairy Sci. 90, 2797-2803.

Cleves, M., Gould, W., Gutierrez, R. G. and Marchenko, Y. V. (2010): An Introduction to Survival Analysis Using Stata. Stata Press, USA. 372 pp.

Dubuc, J., Duffield, T. F., Leslie, K. E., Walton, J. S. and LeBlanc, S. J. (2010): Risk factors for postpartum uterine diseases in dairy cows. J. Dairy Sci. 93, 5764-5771.

Elkjær, K., Labouriau, R., Ancker, M. L., Gustafsson, H. and Callesen, H. (2013): Practical use of a uterine score system for predicting effects on interval from calving to first insemination and non-return rate 56 in Danish dairy herds. Vet. J. 198, 644-648.

Esposito, G., Irons, P. C., Webb, E. C. and Chapwanya, A. (2014): Interactions between negative energy balance, metabolic diseases, uterine health and immune response in transition dairy cows. Anim. Reprod. Sci. 144, 60-71. 
Földi, J., Kulcsár, M., Pécsi, A., Huyghe, B., de Sa, C., Lohuis, J. A., Cox, P. and Huszenicza, G. (2006): Bacterial complications of postpartum uterine involution in cattle. Anim. Reprod. Sci. 96, 265-281.

Fourichon, C., Seegers, H. and Malher, X. (2000): Effect of disease on reproduction in the dairy cow: a meta-analysis. Theriogenology 53, 1729-1759.

Gröhn, Y. T., Erb, H. N., McCulloch, C. E. and Saloniemi, H. S. (1989): Epidemiology of metabolic disorders in dairy cattle: Association among host characteristics, disease, and production. J. Dairy Sci. 72, 1876-1885.

Hadley, G. L., Wolf, C. A. and Harsh, S. B. (2006): Dairy cattle culling patterns, explanations, and implications. J. Dairy Sci. 89, 2286-2296.

Han, Y. K. and Kim, I. H. (2005): Risk factors for retained placenta and the effect of retained placenta on the occurrence of postpartum diseases and subsequent reproductive performance in dairy cows. J. Vet. Sci. 6, 53-59.

Harman, J. L., Gröhn, Y. T., Erb, H. N. and Casella, G. (1996): Event-time analysis of the effect of season of parturition, parity, and concurrent disease on parturition-to-conception interval in dairy cows. Am. J. Vet. Res. 57, 640-645.

Inchaisri, C., Hogeveen, H., Vos, P. L. A. M., van der Weijden, G. C. and Jorritsma, R. (2010): Effect of milk yield characteristics, breed, and parity on success of the first insemination in Dutch dairy cows. J. Dairy Sci. 93, 5179-5187.

Jorritsma, R., Jorritsma, H., Schukken, Y. H. and Wentik, G. H. (2000): Relationships between fatty liver and fertility and some periparturient diseases in commercial Dutch dairy herds. Theriogenology 54, 1065-1074.

Kovács, L., Kézér, F. L. and Szenci, O. (2016): Effect of calving process on the outcomes of delivery and postpartum health of dairy cows with unassisted and assisted calvings. J. Dairy Sci. 99, 7568-7573.

Laster, D. B. and Gregory, K. E. (1973): Factors influencing peri- and early postnatal calf mortality. J. Anim. Sci. 37, 1092-1097.

Maizon, D. O., Oltenacu, P. A., Gröhn, Y. T., Strawderman, R. L. and Emanuelson, U. (2004): Effects of diseases on reproductive performance in Swedish Red and White dairy cattle. Prev. Vet. Med. 66, 113-126.

Mangurkar, B. R., Hayes, J. F. and Moxley, J. E. (1984): Effects of calving ease-calf survival on production and reproduction in Holsteins. J. Dairy Sci. 67, 1496-1509.

Markusfeld, O. (1987): Periparturient traits in seven high dairy herds. Incidence rates, association with parity, and interrelationships among traits. J. Dairy Sci. 57, 725-728.

McDougall, S., Macaulay, R. and Compton, C. (2007): Association between endometritis diagnosis using a novel intravaginal device and reproductive performance in dairy cattle. Anim. Reprod. Sci. 99, 9-23.

Mee, J. F. (1991): Perinatal calf mortality - recent findings. Irish Vet. J. 44, 80-85.

Mee, J. F. (2008): Prevalence and risk factors for dystocia in dairy cattle: A review. Vet. J. 176, 93-101.

Mee, J. F., Berry, D. P. and Cromie, A. R. (2011): Risk factors for calving assistance and dystocia in pasture-based Holstein-Friesian heifers and cows in Ireland. Vet. J. 187, 189-194.

Meyer, C. L., Berger, P. J. and Koehler, K. J. (2000): Interactions among factors affecting stillbirths in Holstein cattle in the United States. J. Dairy Sci. 83, 2657-2663.

Moss, N., Lean, I. J., Reid, S. W. J. and Hodgson, D. R. (2002): Risk factors for repeat-breeder syndrome in New South Wales dairy cows. Prev. Vet. Med. 54, 91-103.

Okawa, H., Fujikura, A., Wijayagunawardane, M. M. P., Vos, P. L. A. M., Taniguchi, M. and Takagi, M. (2017): Effect of diagnosis and treatment of clinical endometritis based on vaginal discharge score grading system in postpartum Holstein cows. J. Vet. Med. Sci. 79, 1545-1551.

Ouweltjes, W., Smolders, E. A. A., Elving, L., Van Eldik, P. and Schukken, Y. H. (1996): Fertility disorders and subsequent fertility in dairy cattle. Livest. Prod. Sci. 46, 213-220. 
Piccardi, M., Romero, G., Veneranda, G., Castello, E., Romero, D., Balzarini, M. and Bó, G. A. (2016): Effect of puerperal metritis on reproductive and productive performance in dairy cows in Argentina. Theriogenology 85, 887-893.

Potter, T. J., Guitian, J., Fishwick, J., Gordon, P. J. and Sheldon, I. M. (2010): Risk factors for clinical endometritis in postpartum dairy cattle. Theriogenology 74, 127-134.

Sheldon, I. M., Cronin, J., Goetze, L., Donofrio, G. and Schuberth, H. J. (2009): Defining postpartum uterine disease and the mechanisms of infection and immunity in the female reproductive tract in cattle. Biol. Reprod. 81, 1025-1032.

Silva del Rio, N., Stewart, S., Rapnicki, P., Chang, Y. M. and Fricke, P. M. (2007): An observational analysis of twin births, calf sex ratio, and calf mortality in Holstein dairy cattle. J. Dairy Sci. 90, 1255-1264.

Szenci, O. (2016): Recent possibilities for diagnosis and treatment of post parturient uterine diseases in dairy cow. J. Fertil. In Vitro IVF Worldw. Reprod. Med. Genet. Stem Cell Biol. 4, 170. doi:10.4172/2375-4508.1000170

Szenci, O. and B. Kiss, M. (1982): Perinatal calf losses in large cattle production units. Acta Vet. Hung. 30, 85-95.

Szenci, O., Horváth, É. and Törös, I. (1987): Control of calvings on a large-scale Holstein-Friesian dairy farm [in Hungarian, with English abstract]. Magy. Allatorvosok 42, 359-365. 